\title{
Nutritional and microbial quality of dried larva of Cirina forda
}

\author{
Bibiana Dooshima Igbabul", Chia Agude, Comfort Ufot Inyang \\ Department of Food Science and Technology, College of Food Technology, University of Agriculture, P.M.B.2373, Makurdi, Benue State, \\ Nigeria
}

\author{
Email address: \\ bibideke@yahoo.com (B. D. Igbabul)
}

\section{To cite this article:}

Bibiana Dooshima Igbabul, Chia Agude, Comfort Ufot Inyang. Nutritional and Microbial Quality of Dried Larva of Cirina forda. International Journal of Nutrition and Food Sciences. Vol. 3, No. 6, 2014, pp. 602-606. doi: 10.11648/j.ijnfs.20140306.28

\begin{abstract}
The quality of dried larva of pallid emperor moth (Cirina forda) sold in various markets of Makurdi metropolis in Nigeria was evaluated. The proximate composition, amino acid profile, mineral contents as well as microbial quality of dried larva of Cirina forda were determined using standard methods. The results of proximate composition on dry basis showed that crude protein ranged from 54.36-56.78\%; ash, 2.91-3.97\%; crude fibre, 11.03-11.15\% and moisture, 4.41-5.95\% The mineral contents, $\mathrm{K}, \mathrm{Na}, \mathrm{Cu}, \mathrm{Fe}, \mathrm{Zn}, \mathrm{Mn}$ and $\mathrm{Mg}$ of the larva samples ranged from 7.67 to $14.39,0.93$ to $1.27,0.11$ to $0.37,0.37$ to $0.56,0.13$ to $0.56,0.28$ to 0.39 and 0.10 to $0.21 \mathrm{mgg}^{-1}$ (dry matter), respectively. Results of the content of amino acids showed the essential amino acids: - isoleucine, leucine, methionine, phenylalanine, threonine, valine and lysine in the ranges of 3.27 to $4.31,6.55$ to $7.57,2.22$ to $2.48,4.47$ to $5.08,3.22$ to $4.18,3.18$ to 4.18 and 5.33 to $6.24 \mathrm{~g} / 100 \mathrm{~g}$ protein respectively. The total viable count of micro organisms in the samples ranged from 2.0 to $3.7 \times 10^{3} \mathrm{cfu} / \mathrm{g}$ and the mold counts were $<30 \mathrm{cfu} / \mathrm{g}$ in all samples. Micro organisms identified included Escherichia coli, Salmonella spp, Staphylococus aureus, Proteus spp, Micrococcus spp, Mucor spp, Aspergillus niger and Rhizopus spp. The nutritional content of the dried larva of Cirina forda compared favourably with those of conventional foods of animal origin and the microbial load of the dried larva within acceptable range. However, the dried larva should be subjected to further heating such as cooking to destroy the pathogens isolated which will otherwise constitute a health risk to consumers.
\end{abstract}

Keywords: Quality, Dried Larva, Cirina forda

\section{Introduction}

Edible insects have played an important part in the history of human nutrition in Africa, Asia and Latin America [1] . It has also been used for cultural (rituals) as well as for medicinal purposes throughout much of man's ancient times and the present. Edible insects have been shown to contain appreciable amount of protein of good quality and are highly digestible. $[2,3,4]$.

In some African regions such as Malawi, Zambia and Tanzania, children fight malnutrition by eating flour made out of dried caterpillars. Pregnant and nursing women as well as anaemic patients also eat caterpillar species high in protein, calcium and iron.

Pallid emperor moth (Cirina forda) is one of the most widely eaten insects in Southern Nigeria [5] and it has been reported as the third most consumed insect in Benue State, Nigeria [6]. The larva of this insect is a delicacy served as a snack food item or taken with carbohydrate food in Nigeria. It is eaten raw or roasted or dried and added to other foods especially carbohydrate to enhance its nutritional value.

It has been shown that the larva of Cirina forda (West wood) has the potential to provide substantial amounts of proteins, minerals and polyunsaturated fatty acids to the diets which are usually deficient in animal protein [7]. Another study in which the larva was processed by boiling, followed by sun drying has shown that such processed larva of Cirina forda (Westwood) was neither neurotoxic nor heptatoxic to mice and rats [8].

Although some reports have been written on edible insects, $[9,10,11,12]$ little information is available on the nutritional quality and none on the microbiology of pallid emperor moth consumed in Makurdi metropolis, Nigeria. The result of this study will contribute to the update of the food composition database of the larva as food and aid in the usage for food product formation and development for better utilization. 


\section{Materials and Methods}

\subsection{Sample Preparation}

Dried Cirina forda larvae were purchased from different markets in Makurdi metropolis of Nigeria. The samples were further sun dried to eliminate excess moisture and ground into powdered form using attrition mill. It was kept in air tight, transport plastic containers until required.

\subsection{Chemical Analysis}

\subsubsection{Proximate Analysis}

The moisture content, ash, crude fat, crude protein and fibre were determined by methods described by AOAC [12]. The carbohydrate content of the ground larva sample was determined by difference as reported by [14].

\subsubsection{Amino Acid Analysis}

The amino acid profile of the ground larva samples was determined by the method described by AOAC [12] in which $2 \mathrm{~g}$ of the samples was dried to constant weight and defatted with chloroform/methanol (2:1 mixture) using soxhlet apparatus for 15 hours. This was followed by nitrogen determination of the sample, hydrolysis of the sample, evaporation in a rotary evaporation and loading $(5-10 \mu l)$ into the Technicom Sequential Multisample Amino Acid Analyser (TSM, model DNA 0209). The net height of each chromogram peak produced by the chart recorder by TSM (each representing an amino acid) was measured. The half height of the peak on the chart was found and width of the peak was then obtained by multiplying the height with the width at half height. The concentration for each amino acid was accordingly obtained from the standard formula.

\subsection{Minerals Analysis}

The wet ashing method described by AOAC [12] was used to determine the mineral content of Cirina forda samples. Here, $2.5 \mathrm{~g}$ of air dried sample was wet with water, $25 \mathrm{ml}$ of nitric acid and the mixture was gently heated to start a sample reaction. After cooling, $10 \mathrm{ml}$ of perchloric acid was added and gently heated to concentrate midway. On becoming dark, $2-3 \mathrm{ml}$ of nitric acid was added and heating was continued until decomposition was completed as material turned yellowish or colourless. After cooling, $2^{\text {nd }}$ of hydrochloric acid and water as used to prepare fixed volumes of measurement solutions. These diluted clear digest were then charred by combustion and the concentrations of each element was read by the atomic absorption spectrophotometer (Model, Buck 210) using lamps with wavelength that matches that of the corresponding element(s), which were iron, zinc, copper, manganese and magnesium. For the determination of potassium and sodium, the flame photometer (model PF-P7) was used to give direct read-out instead of concentrations. Calibration curves were prepared for each element using standard solutions. The appropriate lamps and correct wavelength for each element were adhered to as specified on the instruction manual of the instrument.

\subsection{Microbiological Analysis}

Enumeration, isolation and identification of bacteria contaminating the samples was carried out. Total aerobic plate count was done according to procedures described by [14]. Ten grams of each of the ground larva samples was weighed into $90 \mathrm{ml}$ of sterile peptone water and 10-fold serial dilution carried out. Aliquot ( $1 \mathrm{ml})$ of selected dilution was cultured by pour plate method using plate count agar and incubating at $37^{\circ} \mathrm{C}$ for $48 \mathrm{~h}$. Selective media such as Eosin Methylene Blue Agar (EMBA), Salmonella-Shigella Agar (SSA) and Mannitol salt Agar (MSA), were used to enumerate and isolate pathogens such as E. coli, salmonella and Staphylococcus aureus, respectively. Colonies in duplicate plates were counted and subcultured until pure. Various biochemical tests were used to confirm the identity of the species as outlined in Bergey's Manual of determinative bacteriology [15] yeasts and mould counts were also determined using pour plate method earlier described. Potato Dextrose Agar acidified with $1 \mathrm{ml}$ of $10 \%$ tartaric acid was used for cultivation and incubation was at $28^{\circ} \mathrm{C}$ for $3-5$ days. The species of yeasts and moulds were confirmed on the basis of cultural and morphological characteristic.

\subsection{Statistical Analysis}

Values obtained in the various analyses were subjected to analysis of variance (ANOVA) and Tukey's Least Significance Difference between mean values was determined as outlined by [13].

\section{Results}

The results of proximate composition of Cirina forda on dry weight basis showed very high protein values of $54.36 \%$ to $56.78 \%$ and fat values ranges from $11.07 \%$ to $13.84 \%$. The ash and fibre contents ranged from 2.91 to $3.97 \%$ and 11.03 to $11.15 \%$, respectively (Table 1 ). The moisture was relatively low with values ranging from 4.41 to $5.95 \%$, while carbohydrate values ranged from 11.09 to $12.84 \%$. All parameters showed significant difference $(\mathrm{P}<0.05)$ in their mean values except carbohydrates among samples obtained from different locations (Table 1).

Table 1. Proximate Composition of Cirina forda on Dry Basis

\begin{tabular}{lllll}
\hline \% Content & Sample A & Sample B & Sample C & LSD \\
\hline Crude protein & $56.78^{\mathrm{a}} \pm 0.002$ & $54.36^{\mathrm{b}} \pm 0.002$ & $55.17 \mathrm{c} \pm 0.001$ & 0.13 \\
Carbohydrate & $11.09^{\mathrm{a}} \pm 0.024$ & $12.84^{\mathrm{a}} \pm 0.097$ & $12.16^{\mathrm{a}} \pm 0.097$ & - \\
Ash & $3.97^{\mathrm{a}} \pm 0.001$ & $3.76^{\mathrm{b}} \pm 0.002$ & $2.91^{\mathrm{c}} \pm 0.000$ & 0.08 \\
Crude fibre & $11.15^{\mathrm{a}} \pm 0.000$ & $11.03^{\mathrm{b}} \pm 0.000$ & $11.07^{\mathrm{a}} \pm 0.000$ & 0.05 \\
Fats & $11.07^{\mathrm{a}} \pm 0.003$ & $13.60^{\mathrm{b}} \pm 0.080$ & $13.84^{\mathrm{a}} \pm 0.000$ & 1.26 \\
Moisture & $5.95^{\mathrm{a}} \pm 0.000$ & $4.41^{\mathrm{b}} \pm 0.000$ & $4.86^{\mathrm{c}} \pm 0.000$ & 0.05 \\
\hline
\end{tabular}

Any two means values bearing the same superscript in the same column are not significantly different $(p<0.05)$. Values preceding the means are standard deviations, LSD Least Significantly Differences. Values are means of duplicate determinations.

Sample A: Larva obtained from North Bank Market

Sample B; Larva obtained from Wurukum Market

Sample C: Larva obtained from Modern Market 
The larva of Cirina forda was observed to contain the elements; Potassium, Iron, Manganese, Sodium and Copper. Potassium had the highest value ranging among samples from 7.67 to $14.39 \mathrm{mgg}^{-1}$, whereas Magnesium had the least values ranging from 0.93 to 1.27 , Iron $(0.37$ to 0.56$)$, Zinc ( 0.13 to 0.56 ), Manganese ( 0.28 to 0.37 ) and Copper ( 0.11 to 0.37 ) ppm, respectively (Table 2).

Table 2. Mineral Elements of Cirina forda sold in Makurdi metropolis

\begin{tabular}{lllll}
\hline (mg/g) & & & & \\
\hline Mineral & Sample A & Sample B & Sample C & LSD \\
\hline Potassium & $14.39^{\mathrm{a}} \pm 0.000$ & $7.71^{\mathrm{b}} \pm 0.005$ & $7.67^{\mathrm{b}} \pm 0.008$ & 0.13 \\
Sodium & $0.93^{\mathrm{a}} \pm 0.013$ & $1.07^{\mathrm{a}} \pm 0.005$ & $1.27^{\mathrm{a}} \pm 0.013$ & - \\
Iron & $0.37^{\mathrm{a}} \pm 0.000$ & $0.47^{\mathrm{b}} \pm 0.000$ & $0.56^{\mathrm{c}} \pm 0.000$ & 0.01 \\
Zinc & $0.13^{\mathrm{a}} \pm 0.000$ & $0.47^{\mathrm{b}} \pm 0.000$ & $0.56^{\mathrm{c}} \pm 0.000$ & 0.02 \\
Copper & $0.11^{\mathrm{a}} \pm 0.000$ & $0.13^{\mathrm{a}} \pm 0.000$ & $0.37^{\mathrm{a}} \pm 0.000$ & - \\
Manganese & $0.34^{\mathrm{a}} \pm 0.000$ & $0.28^{\mathrm{b}} \pm 0.000$ & $0.39^{\mathrm{c}} \pm 0.000$ & 0.03 \\
Magnesium & $0.16^{\mathrm{a}} \pm 0.000$ & $0.21^{\mathrm{b}} \pm 0.000$ & $0.10^{\mathrm{c}} \pm 0.000$ & 0.04 \\
\hline
\end{tabular}

Any two means values bearing the same superscript in the same column are not significantly different $(\mathrm{p}<0.05)$. Values preceding the means are standard deviations, LSD Least Significantly Differences. Values are means of duplicate determinations.

Sample A: Larva obtained from North Bank Market

Sample B; Larva obtained from Wurukum Market

Sample C: Larva obtained from Modern Market

Table 3. Amino acids profile of Cirina forda sold in Makurdi metropolis

\begin{tabular}{lllll}
\hline g/100g protein & & & & \\
\hline Amino acid & Sample A & Sample B & Sample C & LSD \\
\hline Lysine & $5.64^{\mathrm{a}} \pm 0.000$ & $5.33^{\mathrm{b}} \pm 0.000$ & $6.24^{\mathrm{c}} \pm 0.000$ & 0.04 \\
Histidine & $2.57^{\mathrm{a}} \pm 0.004$ & $2.32^{\mathrm{b}} \pm 0.002$ & $2.40^{\mathrm{b}} \pm 0.000$ & 0.09 \\
Arginine & $6.78^{\mathrm{a}} \pm 0.004$ & $5.48^{\mathrm{b}} \pm 0.026$ & $5.02^{\mathrm{c}} \pm 0.000$ & 0.20 \\
Aspartic & $8.65^{\mathrm{a}} \pm 0.029$ & $8.69^{\mathrm{a}} \pm 0.000$ & $9.43^{\mathrm{b}} \pm 0.002$ & 0.17 \\
Cystine & $1.45^{\mathrm{a}} \pm 0.062$ & $1.28^{\mathrm{a}} \pm 0.000$ & $1.07^{\mathrm{b}} \pm 0.000$ & - \\
Valine & $3.18^{\mathrm{a}} \pm 0.010$ & $4.18^{\mathrm{b}} \pm 0.000$ & $4.05^{\mathrm{c}} \pm 0.001$ & 0.12 \\
Glycine & $3.80^{\mathrm{a}} \pm 0.016$ & $4.07^{\mathrm{b}} \pm 0.000$ & $2.72^{\mathrm{b}} \pm 0.000$ & 0.44 \\
Alanine & $4.31^{\mathrm{a}} \pm 0.007$ & $3.63^{\mathrm{b}} \pm 0.002$ & $4.34^{\mathrm{a}} \pm 0.000$ & 0.13 \\
Threonine & $4.18^{\mathrm{a}} \pm 0.023$ & $3.94^{\mathrm{b}} \pm 0.003$ & $3.22^{\mathrm{c}} \pm 0.000$ & 0.18 \\
Cerine & $3.03^{\mathrm{a}} \pm 0.004$ & $3.31^{\mathrm{b}} \pm 0.000$ & $2.91^{\mathrm{c}} \pm 0.004$ & 0.08 \\
Glutamic & $14.34^{\mathrm{a}} \pm 0.058$ & $13.41^{\mathrm{b}} \pm 0.000$ & $12.24^{\mathrm{c}} \pm 0.000$ & 0.28 \\
Croline & $3.12^{\mathrm{a}} \pm 0.002$ & $2.34^{\mathrm{b}} \pm 0.004$ & $2.74^{\mathrm{c}} \pm 0.002$ & 0.11 \\
Methionine & $2.35^{\mathrm{a}} \pm 0.030$ & $2.38^{\mathrm{a}} \pm 0.093$ & $2.22^{\mathrm{a}} \pm 0.000$ & - \\
Isoleucine & $3.27^{\mathrm{a}} \pm 0.007$ & $3.37^{\mathrm{b}} \pm 0.000$ & $4.31^{\mathrm{b}} \pm 0.000$ & 0.09 \\
Leucine & $7.51^{\mathrm{a}} \pm 0.000$ & $7.26^{\mathrm{b}} \pm 0.002$ & $6.55^{\mathrm{c}} \pm 0.000$ & 0.05 \\
Tyrosine & $2.74^{\mathrm{a}} \pm 0.000$ & $3.205^{\mathrm{b}} \pm 0.003$ & $3.53^{\mathrm{c}} \pm 0.002$ & 0.08 \\
Phenyalanine & $5.08^{\mathrm{a}} \pm 0.007$ & $4.90^{\mathrm{b}} \pm 0.000$ & $4.57^{\mathrm{c}} \pm 0.000$ & 0.10 \\
\hline
\end{tabular}

Any two means values bearing the same superscript in the same column are not significantly different $(\mathrm{p}<0.05)$. Values preceding the means are standard deviations, LSD Least Significantly Differences. Values are means of duplicate determinations.

Sample A: Larva obtained from North Bank Market

Sample B; Larva obtained from Wurukum Market

Sample C: Larva obtained from Modern Market
The amino acid profile of larva of Cirina forda shows the presence of isoleucine, leucine, methionine, phenylalanine, threonine, valine, lysine at varying amount and other nonessential amino acids at low but measurable levels (Table 3). The essential amino acids of Cirina forda, its daily requirement as well as the mass $(\mathrm{g})$ of the larva required for the daily minimum requirements are reported in Table 4.

The microbial load of the larva revealed total viable count of 2.0 to $3.7 \times 10^{3} \mathrm{cfu} / \mathrm{g}$ and total fungal count of $<30 \mathrm{cfu} / \mathrm{g}$ (Table 5). Predominant organisms isolated from the larva included Escherichia coli, Salmonella spp, Staphylococcus aureus, Micrococcus sp, Proteus sp, and the fungi Aspergillus niger, Mucor sp and Rhizopus sp (Table 6 and Table 7).

Table 4. Essential amino acid profile of Cirina forda and daily requirement

\begin{tabular}{llll}
\hline Amino acid & $\begin{array}{l}\text { Average acid } \\
\text { content } \\
(\mathbf{m g} / \mathbf{1 0 0 g})\end{array}$ & $\begin{array}{l}\text { DMR } \\
\text { (mg) }\end{array}$ & $\begin{array}{l}\text { Minimum mass (g) } \\
\text { of insect required } \\
\text { for DMR }\end{array}$ \\
\hline Isoleucine & 365 & $450-700$ & 123 \\
Leucine & 711 & $620-1100$ & 87 \\
Methionine & 235 & $550-1100$ & 234 \\
Phyenylalanine & 485 & $220-1100$ & 45 \\
Threonine & 378 & $310-500$ & 82 \\
Valine & 380 & $650-800$ & 171 \\
Lysine & 574 & $500-800$ & 87 \\
\hline
\end{tabular}

DMR- Daily Minimum Requirement

Table 5. Microbial load of dried larva of Cirina forda

\begin{tabular}{lll}
\hline $\begin{array}{l}\text { Samples from } \\
\text { various locations }\end{array}$ & $\begin{array}{l}\text { Total viable count } \\
\text { (cfu/g)* }\end{array}$ & $\begin{array}{l}\text { Total fungal } \\
\text { count(cru/g) }\end{array}$ \\
\hline North Bank Market & $3.7 \times 10^{3}$ & $<30$ \\
Wurukum Market & $2.0 \times 10^{3}$ & $<30$ \\
Modern Market & $2.3 \times 10^{3}$ & $<30$ \\
\hline
\end{tabular}

*Mean value of duplicate determination

Table 6. Mould Isolates of Cirina forda sold in Makurdi metropolis

\begin{tabular}{llll}
\hline $\begin{array}{l}\text { Samples bought } \\
\text { different locations }\end{array}$ & Isolates & $\begin{array}{l}\text { Growth } \\
\text { rate/days }\end{array}$ & Cfu/g \\
\hline North Bank Market & Mucor sp & $2-3$ & $<30$ \\
Wurukum Market & Aspergillus niger & 3 & $<30$ \\
Modern Market & Rhizopus and Mucor spp & 3 & $<30$ \\
\hline
\end{tabular}

Table 7. Cutural and Biochemical characteristics of bacterial isolates

\begin{tabular}{|c|c|c|c|c|c|}
\hline Isolate Code & $\mathbf{N B}_{1}, \mathbf{W M}_{1}$ & $\mathbf{N B}_{2}, \mathbf{W M}_{3}$ & $\mathbf{M M}_{2}, \mathbf{N B}_{3}$ & $\mathbf{W M}_{2}$ & $\mathbf{M M}_{1}$ \\
\hline Gram's reaction & - & - & + & + & - \\
\hline Catalase & + & + & + & + & + \\
\hline Oxidase & - & - & - & + & - \\
\hline Coagulase & - & - & + & - & - \\
\hline Indole & + & - & - & - & + \\
\hline VP & - & - & + & - & - \\
\hline MR & + & + & + & & + \\
\hline
\end{tabular}




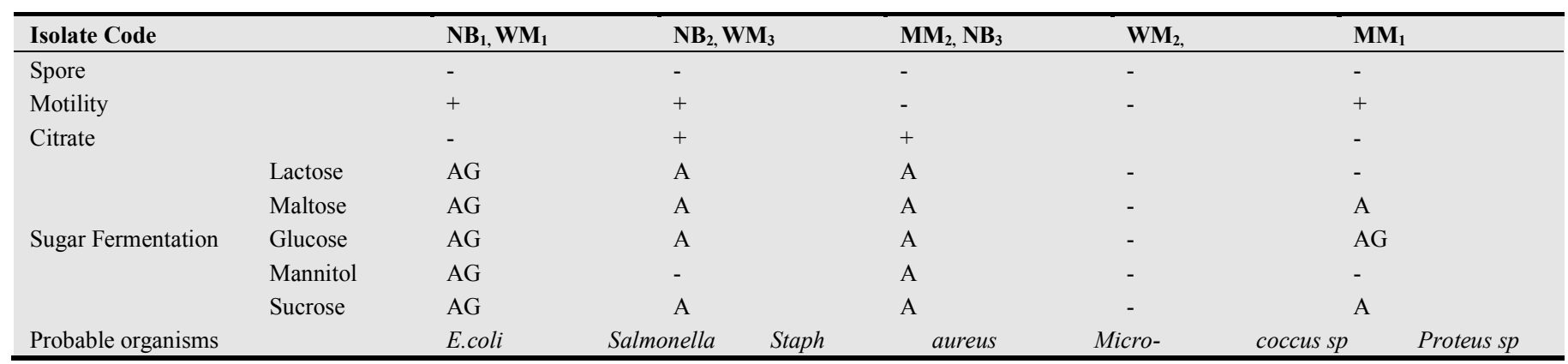

Key to Table 7

$\mathrm{NB}=$ North Bank Market

$\mathrm{WM}=$ Wurukum market

$\mathrm{MM}=$ Modern market

$+=$ Positive

-=Negative

$\mathrm{A}=$ Acid production

$\mathrm{G}=\mathrm{Gas}$ production

\section{Discussion}

The dried larva of Cirina forda had high protein and fat values (Table1). The crude protein content of $55.44 \%$ falls within the protein range of $55-60 \%$ previously reported for various forms of lepidopterous edible insects from the state of Mexico [4] and that of Cirina forda (55.5\%) reported by [10]. However, the value was higher than the protein value (33.12\%) of Cirina forda reported by [7]. This protein content obtained for Cirina forda in this study falls within the range of $23-60 \%$ recommended as daily protein requirement. Although whole insects as a source of protein are of somewhat lower quality than vertebrate animal products because of the indigestibility of chitin, the consumption of the caterpillars can supplement to a substantial degree some of the nutrients inadequate in cereals. Insect proteins have been recommended as a supplement for high cereal diets and weaning foods for infants $\mathrm{FAO} / \mathrm{UN}$ [16]

The high amount of fat recorded (Table 1) is essential in diets as it increases the palatability of foods by absorbing and retaining their flavours. Fats are also vital in the structural and biological functioning of cells and help in the transportation of nutritionally essential fat-soluble vitamins. The low moisture content of the samples is an indication that the samples will have good storage stability if properly packaged. It may have also contributed to the reduction in microbial growth in the samples, possibly extending the shelf-life of the product.

The larva of Cirina forda is observed to be a good source of mineral elements with values for zinc and iron exceeding that reported by [7]. The caterpillars studied by [12], also proved to be excellent source of iron. Since Cirina forda is rich in iron, the blood building element, it would be desirable for human and animal consumption in anaemic conditions. Iron deficiency is a major problem in women's diet in the developing world (Africa), particularly among pregnant women and vegetarians everywhere are known to be at risk of zinc deficiency. Therefore the high content of iron and zinc in many edible insects including Cirina forda and potassium levels of the larva (Table 2) approximately 10:1. This favourable ratio renders the larva of Cirina forda a potential component of diets for the management of hypertension, since it has been documented that potassium intake is useful for lowering blood pressure by antagonizing the biological effect of sodium [17]. The magnesium level of Cirina forda was below its RDA, hence the larva would not be recommended for diet of people in need of magnesium. The nutritional value of the insect as determined by the amino acid composition shows that Cirina forda larva contains all the essential amino acids needed for human growth in nearly optimal proportions, hence can be considered as good quality or complete protein. However, the levels of the amino acids followed the general trend for insects of being low in methionine/cysteine, but high in lysine and threonine.

The total aerobic plate count of about $10^{3} \mathrm{cfu} / \mathrm{g}$ obtained in the samples is within the acceptable limit $\left(10^{4} \mathrm{cfu} / \mathrm{g}\right)$ [18]. It is also lower than the total bacterial counts of $10^{5}-10^{6} \mathrm{cfu} / \mathrm{g}$ observed in smoked meat product ("suya") [19]. Contamination of the samples by pathogens could have resulted during processing and handling. [19] also smoked meat product 'suya'.

\section{Conclusion}

The results of this study showed that the nutritional content of dried larva of Cirina forda compares favourably with those of conventional foods of animal origin. Hence, it has the potential to provide substantial amounts of protein, essential amino acids and minerals to the diet of low income people in the area of study (Makurdi metropolis), whose diets are usually deficient in animal protein, thereby alleviating their problem of protein malnutrition. The microbial load of the dried larva was within acceptable range. However, observed contamination with pathogens such as Salmonella, E. coli and Staphylococcus aureus could constitute health risk to consumers. The dried larva should therefore be subjected to further heating such as cooking before consumption. 


\section{References}

[1] Banjo, A.D; O.A. Lawal and E.A. Songonuga (2006). The nutritional value of fourteen species of edible insects in south western Nigeria. Afr. J. Biotechnol. 5 (3): 298-301.

[2] Ashiru, M.O(1988). The Food Value of Larva of Anapheveneta butler (Lepidoptera notodontidae). Ecol. Fd. Nutri. 22: 313-320

[3] DeFoliart, G.R (1999). Insects as food : Why the Western attitude is important. Ann Enotomol 44: 21-30.

[4] Ramos-Elorduy, J; J.M. Moreno; E.E. Prado and J.L. Otero (1997). The nutritional value of edible insects from the state of Mexico. J. Fd Composition and Analysis 10:142-147.

[5] Fasoranti, J.O and D.O. Ajiboye (1993). Some edible insects of Kwara State, Nigeria. America Entomologist 39: 113-116.

[6] Agbidye, F.S; S.O. Akindele and T.I. Ofuya (2009). Some edible insect species consumed by the people of Benue state, Nigeria. Pakistan Journal of Nitrition 8:946-950.

[7] Akinnawo, O.O and A.O. Ketiku (2000). Chemical composition and fatty acid profile of edible larva of Cirina forda. Afr. J. Biomed.Res.3:93-97.

[8] Akinnawo, O.O, M.O. Abatan and A.O. Ketiku (2002). Toxicological study on the edible larva of Cirina forda. Afr.J. Biomed. Res. 5:43-46.

[9] Oliveira, J.F; J.P. Decarvalhol and M.M. Simao (1976). The nutritional value of four species of insects consumed in Angola. Ecol. Food Nutri. 5:91-95.

[10] Omotosho,O.T (2005).Nutritional quality, functional properties and antinutrient composition of the larva of Cirina forda. Journal of Zhejiang University Science 7(1):51-55.

[11] Allotey,J and M. Sisai (2003). Utilization of useful insects as food sources. Afr. J.Fd Agric. Nutri. Dev 3 (2): 273-279.

[12] AOAC (2000). Official Methods of Analysis. Association of Official Analytical Chemistry, Washington, D.C.

[13] Ihekoronye, A.I and P.O. Ngoddy (1985). Integrated Food Science and Technology for the Tropics. Maxwell Publishers, London. pp 372-376

[14] Harrigan, W.F and M.E. McCance (1976). Laboratory methods in Food Dairy Microbiology. Academic Press, London. Pp 753-770.

[15] Holt, J.G; N.R. Krieg, P.H.A Sneath, J.T. Staley and S.T. Williams (1994). Bergey's manual determinative bacteriology. $9^{\text {th }}$ ed. Williams and Wilkins, Baltimore, USA.

[16] FAO/UN (2004). Edible insects are important source of protein. UN News Service, online at www.wholibdoc.who.int/trs/WHO retrieved May 4, 2014.

[17] Allan, G.C and A.F. Brian (1989). Food Science, Nutrition Group, London $5^{\text {th }}$ ed. Pp 365-367.

[18] ICMSF (1986). International Commission on Microbiological Specification for Foods. Blackie Academic \& Professional, London, New York, Tokyo. Madras.

[19] Inyang, C.U.; M.A. Igyor and E.N. Uma (2005). Bacterial quality of a smocked meat product ("suya"). Nig. Food Journal 23: 239-242 